\title{
Committee Power and Amendment Rights in the U.S. House
}

\author{
Charles J. Finocchiaro and Bryan W. Marshall
}

Much of the extant literature on legislative organization treats Congress' jurisdictional framework as an exogenous facet of the political landscape. While bill referral and statutory rules are key institutional determinants shaping the politics of committee jurisdiction, we argue that important choices affecting committee power occur at post-referral stages of the legislative process, including actions taken by the Rules Committee. The analysis suggests that variation in amendment challenges to committee bills resulting from special rule decisions is systematically affected by key factors related to organizational theories of Congress. The findings have at least two important implications for committee power in the U.S. House. Special rule decisions can shape committee power by closing or opening access to committee products bill by bill. This result diminishes the significance of prior referral decisions granting committees the prerogative to exercise uninhibited discretion over policies within their jurisdiction. Furthermore, the findings demonstrate that patterns in amendment rights conferred by special rules respond systematically to majority party interests.

Much of the scholarly attention on jurisdictional politics has focused on the significance of bill referral in explaining committee control over policy areas (Shipan 1992; King 1997). Others have examined the role of committee actions in driving jurisdictional fragmentation (Jones, Baumgartner, and Talbert 1993). Yet relatively little attention has been given to the many post-referral decisions that can be made by the Speaker, conference committees, and the Rules Committee in shaping a committee's control over its bills. The question of committee power hinges directly on a committee's ability to guard its turf and thereby exercise control over issues falling within its jurisdiction. It is certainly true that jurisdictions provide committees with important ex ante power as policy gatekeepers. But, this power is far less valuable if it is not coupled with ex post powers that provide committees with control over their bills at later stages in the legislative process (Shepsle and Weingast 1987). ${ }^{1}$ We suggest that the Rules Committee-with its discretion over amendment rights - can have an important impact on the power of substantive committees and their prerogative on the floor to control bills within their jurisdiction.

Indeed, the Rules Committee often plays a pivotal role in determining the relative level of control committees enjoy over their bills. Take, for example, minority complaints during the rule debate in the 105th Congress

CHARLES J. FINOCCHIARO is an assistant professor of political science at the University of Buffalo, SUNY. BRYAN W. MARSHALL is an assistant professor of political science at Miami University in Oxford, Ohio.

The American Review of Politics, Vol. 25, Fall, 2004: 265-284

(C)2004 The American Review of Politics 
regarding the handling (or mishandling) of two bills: HR 1486, the Foreign Policy Reform Act and HR 1757, the Foreign Relations Authorization Act.

\begin{abstract}
Mr. Speaker, a funny thing happened in the Committee on Rules last night. For $31 / 2$ hours we took testimony on HR $1486 \ldots$. . But at 8:30 last night, HR 1486 disappeared. Instead, plopped on our desk was HR 1757 which is a 185 page bill fresh from the printer, never before seen by anyone in the room. ... This kind of procedure is unfair to the members of the Committee on Rules, it is unfair to the Members who testified, it is unfair to all House Members who are confronted with a new bill and have only hours to read it and prepare new amendments. Furthermore, it undermines the credibility of the Committee on Rules and the committee system. If the Committee on Rules is going to report out bills that we have never seen, we do not need a Committee on Rules. Perhaps instead we should appoint a search committee to find what happened to the Foreign Policy Reform Act (Quote from Representative Hall [D-OH], CR H3282, 6/4/1997).
\end{abstract}

On the face of it, there is little reason to suspect that these bills would spark such sharp controversy. In fact, both bills were singly referred to the House International Relations Committee and HR 1757 was passed via voice vote on the House floor. ${ }^{2}$ Yet the actions taken by the Rules Committee made consideration of the bill and the role of the referral committee anything but routine.

Representative Hamilton (D-IN), ranking minority member of the International Relations Committee, also fumed about the Rules Committee's handling of his committee's bill.

In my view, this rule is offensive to the Committee on International Relations. It disregards totally the committee's work product. It is an extraordinary exercise of power, if not an usurpation of power by the Committee on Rules. ... It [the Rules Committee] ought not to ignore the committee product. ... It torpedoes the committee, it sets aside the committee's expertise, and I object to it (CR H3287 6/4/1997).

More recent action during the 107th Congress found the Rules Committee embroiled more directly in jurisdictional politics, this time as the mediator between two panels - the Energy and Commerce Committee and the Judiciary Committee. The inter-committee fight was over the Internet Freedom and Broadband Deployment Act of 2000 also known as the TauzinDingell bill (HR 1542) - a bill that would deregulate internet service markets $(C Q W 6 / 16 / 01,1434-1435)$. Although there were signs of conflict over the bill, they were not distinctly partisan. The bill was first passed by the Energy and Commerce Committee before being sent to the Judiciary Committee, which was to selectively address antitrust issues only. Judiciary Committee members clearly opposed the original bill and sought to kill it if 
the narrow referral would not allow them to produce a bill more to their liking. The Judiciary Committee passed an amendment to the bill that would reverse some of the deregulation language and then unfavorably reported the measure. The author of the amendment and Chairman of the Judiciary panel, F. James Sensenbrenner, Jr. (R-WI), argued that the amendment was designed to "help preserve his panel's future jurisdictional interests" (CQW 6/16/01, 1435). Energy and Commerce Committee supporters clearly took an alternative view of the jurisdictional boundaries in the bill. Rick Boucher (D-VA) said:

I think it's clear that this is as far as the amendment goes, and no further. We're going to stake our case in the Rules Committee on the procedural grounds that this is language that goes well beyond the scope of the referral $(C Q W 6 / 16 / 01,1435)$.

Ultimately, Sensenbrenner's entrepreneurial efforts were to no avail as the Rules Committee provided a special rule that preserved the Energy and Commerce Committee's control over the bill. ${ }^{3}$

The committee battles exemplified in these debates illustrate a couple of key points. As evidenced by both of the above anecdotal accounts, issues related to committee power can hinge directly on decisions made by the Rules Committee. Second, as the latter example illustrates, the assumption that committee jurisdictions are exogenous can be compromised by procedural decisions on special rules. Even more, we suggest that special rule decisions represent more than just tinkering, but systematically impact a committee's ability to control legislation by affecting amending activity on the floor. Taken together, these anecdotal accounts seem to call into question the significance of the referral process as the institutional epicenter affecting committee power.

King (1997) has demonstrated that bill referral decisions are integral in shaping the politics of committee jurisdiction. While King's work certainly offers a useful theoretical framework at the referral stage, there exist other potentially important post-referral decisions that can affect jurisdictional boundaries and the degree of control committees wield over bills within those boundaries. Importantly, we do not challenge King's analysis, nor do we claim that procedural choices in special rules alter the permanent jurisdictional boundaries of committees. Rather, our analysis explores a different angle on committee turf and power-one that suggests procedural choices confer amendment rights bill by bill and thereby significantly impact the level of control committees exercise over those policies that fall within their jurisdictions. In this way, our analysis represents an extension of King's work in that its focus on amendment rights illustrates the important linkage between committee jurisdictions and committee power. 
This analysis moves beyond the initial stage of bill referral and investigates the impact of procedural choices on committee power. We offer a different perspective of the processes governing turf and amendment rights that supply members with opportunities to challenge committee products. According to this view, special rules serve as a post-referral mechanism that governs amendment rights and thus significantly shapes a committee's power over bills within its jurisdiction. We expand the debate over the politics of turf and committee power by examining patterns of amendment challenges culminating from this post-referral process and test them against explanations inspired by theories of legislative organization. The analysis demonstrates that primarily partisan rationales, alongside some tempered informational considerations, are at work in explaining variation in the extent to which committee control over individual bills (as set forth through committee referral) are protected or left unprotected on the floor. Similar to King's argument, our findings raise important caveats to the conventional view that describes committee jurisdictions as fixed or exogenous (Polsby 1968). Indeed, jurisdictions are most relevant to committee power when committees can protect their bills from challenges later in the legislative process. Our analysis shows that special rules can have profound effects on who has influence over committee products on the House floor. The results not only suggests that the majority party shapes committee power through the granting of amendment rights, but also to some degree shapes the incentives for committee specialization.

\section{Post-referral Jurisdictional Politics: The Role of the Rules Committee}

The role of the Rules Committee as jurisdictional arbiter has long been institutionalized (Oppenheimer 1977, 103). In fact, its powers governing jurisdictional considerations grew with the advent of the referral of bills to multiple committees (Davidson, Oleszek, and Kephart 1988, 26). The new procedure gave rise to heightened levels of inter-committee conflict over a variety of issues, many of which require lengthy and careful negotiations on the part of senior committee members and their staffs. In those instances in which clashing committees are unable to resolve such disputes, the Rules Committee often steps in as the final arbiter.

Although the Rules Committee has no formal control over initial referral decisions, many post-referral avenues exist through which the Rules Committee and the rules process can affect the scope and influence committees have over individual bills within their jurisdictions. Often times, Rules will require rival committees to agree upon a bill and/or set of amendments for floor consideration before granting a special rule (Oleszek 2001, 121). This practice tends to dilute potentially bitter inter-committee floor fights 
and expedites floor consideration. These compromises have increasingly come to be decided by competing committees' majority party members (Bach and Smith 1988, 42). If the inter-committee compromise is unsatisfactory to the Rules Committee, then it can decide not only which legislative vehicle reaches the floor, but also which is considered the original bill and which are considered substitutes for purpose of amendment (Bach and Smith 1988). In addition, the Rules Committee can delay or intentionally stop certain measures the House or majority party does not want to be considered on the floor (Oppenheimer 1977).

There are many other ways that the Rules Committee can affect a committee's ability to protect its turf. For one, the Rules Committee can introduce special rules to extract bills from committee, thereby undermining their gatekeeping authority. More commonly, special rules also influence committee power by determining how much of the committee product will be protected and from which floor amendments. In this way, the Rules Committee grants amendment rights that determine how much of the committee's bill will be opened to floor challenges. Finally, special rules can contain various kinds of waivers that may affect jurisdictional boundaries in specific instances. ${ }^{4}$ Waivers can allow both appropriating and authorizing committees to tread on each other's turf. For example, there are waivers to circumvent House rules relating to authorization language (Rule 21) on appropriations. ${ }^{5}$ Conversely, waivers can allow appropriations in authorization bills. Waivers can also waive germaneness requirements. In effect, these types of waivers can open or protect the jurisdictional boundaries for a particular committee bill depending on the object of the waiver.

The Rules Committee, then, can play a key role in shaping committee power and in sorting out jurisdictional questions in the post-referral stage. However, this does not suggest that Rules Committee actions permanently change committee jurisdictions. But they can and do permit normal jurisdictional boundaries to be infringed upon bill by bill. Special rules determine not only whether a bill (or portion thereof) receives protection from points of order, but can also specify the set of possible amendment challenges. By doing so, special rules govern the degree to which a committee's jurisdictional control of a particular bill will be respected on the floor. Put differently, turf considerations are inherently at stake with special rule decisions that can determine the extent to which non-committee members can breach jurisdictions in specific instances by challenging committee products on the floor. We offer a case study and brief analysis of the 1994 Transportation appropriations bill to illustrate the importance of special rules in determining the politics of turf wars. 


\section{Turf Wars and Special Rules: The Case of the FY1994 Transportation Appropriations Bill}

The turf battle began when the Transportation appropriations bill (HR 2490) was pulled from the floor because members of the Public Works Committee threatened to defeat the special rule. ${ }^{6}$ At issue was a single provision in the bill that earmarked $\$ 305$ million dollars targeting fifty-eight special projects. The Public Works members initiated this revolt because the special projects in the appropriations bill had either not been authorized by them or had been authorized for lesser amounts making the provision in violation of House Rule 21. ${ }^{7}$ Representative Bob Carr (D-MI), the Transportation Appropriations Subcommitttee Chair, had agreed to notify the Public Works Committee Chair, Norman Mineta (D-CA) when the Transportation appropriations bill invaded the authorizing committee's turf. Under the agreement, Chairman Mineta would then have the opportunity to resolve any objections with Chairman Carr and when they could not agree, the leadership would make the final determination. However, Chairman Mineta wanted assurances from the Democratic leadership that he would have the ultimate discretion if the leadership had objections about specific unauthorized projects - a precedent that had been followed in the past.

Certainly then, turf (and the control over policy that accompanies it) was the major concern for both Chairs. Indeed, Chairman Carr suggested that he was willing to work with Mineta, but refused to give him veto power over the projects in his bill. He said "If Mineta was bargaining for a situation that would prevent me from making a few select, unauthorized appropriations, he won't be successful" (CQW 7/24/93, 1946). The House leadership worked toward a compromise between the committees for over two months. When the new rule for the revised Transportation appropriations bill was finally brought to the floor it contained no protections for the unauthorized projects suggesting that the leadership had sided with Chairman Mineta, maintaining the Public Works Committee's discretion over special transportation projects. ${ }^{8}$ The leadership supported the special rule and it was adopted 257-163 [ D $(161,86), \mathrm{R}(95,77)$ ]. Moreover, Chairman Mineta and members of the Public Works Committee were able to exercise their turf rights under the rule by removing from the bill dozens of unauthorized special projects with points of order on the floor.

Although only suggestive, the case of the 1994 Transportation appropriations bill seems to show that a committee's ability to control bills within its jurisdiction (e.g., committee power) can hinge on special rule decisions. We systematically analyzed member behavior on the special rule to see whether or not the actual voting patterns correspond with the turf war explication illustrated by the case study. Table 1 presents a logit model on 
member support for the special rule that brought the 1994 Transportation appropriations bill to the floor. The dependent variable is coded one if the member supported the rule and zero otherwise. The model controls for member ideology (as measured by NOMINATE), party, and most importantly dummy indicators for whether or not members held a seat on the Appropriations Committee or the Public Works Committee. If turf considerations were systematically affecting member behavior, we would expect that members of the Appropriations Committee would be significantly less likely to support the special rule while members of Public Works would support it, all else being equal.

Table 1 shows that ideology, party, and committee membership each significantly impacted member voting behavior on the rule. Similar to the story implied by the case study, the important results here show that members on Appropriations were significantly less likely to support the rule and members on Public works were significantly more likely to support the rule. In particular, membership on Appropriations decreased the probability a member would vote for the rule by 37 percent while membership on Public Works increased the probability a member would vote for the rule by 51 percent. These results demonstrate that a committee's right to exercise control

Table 1. Logit Analysis of the Vote on the Rule for FY 1994 Transportation Appropriations (HR 2750)

\begin{tabular}{|c|c|c|c|}
\hline Variable & Coefficient & $\begin{array}{c}\text { Robust } \\
\text { Standard Error }\end{array}$ & $\Delta \mathrm{P}$ \\
\hline Ideology (NOMINATE) & $-3.54 * *$ & 0.66 & -66.1 \\
\hline Party (Democrat) & $-2.48 * *$ & 0.59 & -47.7 \\
\hline Appropriations Seat & $-2.84 * *$ & 0.42 & -36.6 \\
\hline Public Works Seat & $2.99 * *$ & 0.74 & 50.6 \\
\hline Constant & $1.72 * *$ & 0.34 & \\
\hline $\mathrm{N}$ & & & \\
\hline LL & & & \\
\hline$\chi^{2}$ & & $3 * *$ & \\
\hline Pseudo- $\mathrm{R}^{2}$ & & 25 & \\
\hline$\%$ Correct & & & \\
\hline PRE & & & \\
\hline \multicolumn{4}{|c|}{$\begin{array}{l}\text { Note: Dependent variable is dichotomous, coded } 1 \text { if the member voted for adoption of the rule and } 0 \\
\text { if he/she voted against the rule. Change in predicted probability is based on changes from } 0 / 1 \text { for } \\
\text { dichotomous variables and }+1 /-1 \text { s.d. from the mean for ideology, holding all other variables at their } \\
\text { mean/mode. } \\
\text { * Significant at } p<0.05, * * p<0.01 \text {. }\end{array}$} \\
\hline
\end{tabular}


over bills within their jurisdiction can and do hinge on rule decisions that come after the referral stage. Of course, turf is important to members because of the influence it allows them to have over a segment of public policy. Thus, turf conflict can be overt, as in the case of the transportations appropriations bill, where conflict centered on which committee had the right to exercise authority. Issues of turf also come into play in that legislative bodies often give particular privileges to committees when it comes to considering their policy proposals on the floor. The notion of committee power hinges on the ability of committees to bring about policy change that diverges from the preferences of the full membership of the institution. The Rules Committee serves an important institutional function in its task of determining whether access to committee products on the floor should be granted - a key determinant in shaping committee power and thus the degree to which a committee's control of an issue is protected.

\section{Theories of Legislative Organization and Expectations for Committee Power}

It is true that the Rules Committee seeks to use its institutional position to solve jurisdictional disputes in a manner that enhances the House's ability to legislate (Krehbiel 1991; Oleszek 2001). ${ }^{9}$ Indeed, the Rules Committee controls the flow of legislation, coordinating the actions of panels and the floor (Oppenheimer 1977). However, theories of legislative organization have offered competing explanations regarding factors shaping the powers of the Rules Committee as well as its actions (Dion and Huber 1996; Krehbiel 1997; Marshall 2002; Sinclair 2002). We now turn to these theoretical rationales as they relate to their impact on committee power and the patterns of amendment challenges we would expect to observe if such explanations were at work. In particular, we conceptualize committee power as measured in this analysis in terms of the extent to which a special rule opens up a bill to challenges made by outsiders on the floor.

Three central claims have emerged to explain how Congress distributes its institutional powers and parliamentary rights. Congressional committees represent a key fixture in the debate over congressional institutions. One of these perspectives is informational theory. This theory asserts that the congressional committee system (and congressional institutions more generally) reflects two fundamental ideas, uncertainty and majoritarianism (Krehbiel 1991). According to the theory, special rules can provide a majoritarian solution to policy uncertainty by inducing committees to produce and share expertise with the chamber. In effect, rules are used to protect committee products that are representative of the chamber. Representative committees, then, should be more likely to have bills within their turf boundaries protect- 
ed through special rules that limit the amendment rights of non-committee members who would be interested in undoing the committee's work once a bill reaches the floor. Thus, a committee's power as measured by amendment challenges to bills on the floor should be decreasing with respect to the referral committee's similarity to the chamber median.

Committee representativeness and specialization can be gauged by a variety of factors, including the degree to which a panel is heterogeneous (and thereby produces worthwhile signals to the floor) and the degree to which a committee reflects the preferences of the floor (Krehbiel 1991). Thus, we propose the following informational hypotheses to explain variation in committee power as measured by amendment challenges on the floor: (1) higher levels of committee heterogeneity (in terms of committee composition relative to the floor) will lead to lesser degrees of floor incursion for the committee(s) of referral; (2) committees of referral that are outliers with respect to the floor will receive less protection from amendment challenges; and (3) the greater the degree of specialization necessary on a particular bill, the lesser the degree of amendment challenges the committee(s) of referral is likely to face on the floor.

Another claim provides that there is a distributive rationale governing the design of congressional institutions. According to this view, rule decisions protect the traditional "logroll" agreements that could otherwise unravel among members with diverse policy interests (Weingast and Marshall 1988; Baron and Ferejohn 1989). Rules then are designed to enforce floor protections that help members achieve gains-from-trade (Ferejohn 1974; Mayhew 1974). Some committees are more distributive in nature than others (Deering and Smith 1997). If gains-from-trade is the underlying rationale, then those committees with more narrowly defined jurisdictions that deal primarily with distributive policies should maintain higher levels of committee power and have bills within their jurisdiction protected more so than other committees. Therefore, we test the distributive hypothesis that: (4) bills referred to a constituency (or classic "pork barrel") committee should face fewer outsider amendment incursions on their bills.

A third set of claims emphasizes the centrality of political parties. According to this perspective, the majority party shapes congressional institutions in order to provide collective policy and electoral advantages to its members (Cooper and Brady 1981; Rohde 1991; Sinclair 1992; Cox and McCubbins 1993). Once again, special rules - as they relate to committee power-also have a place in partisan theory (Bach and Smith 1988; Dion and Huber 1996; Aldrich and Rohde 2000; Sinclair 2002). When committees produce legislation that is responsive to the collective concerns of the majority party, special rules should be used to maintain relatively high levels of committee power by limiting outsider amendment challenges on the floor. 
So, policies produced by committees that are more representative of the majority party should receive greater floor protection than those panels that diverge from the majority party's position. In general, though, one would expect amendment challenges against the committee(s) of referral should be decreasing under conditions that would advantage members of the minority party or floor median relative to the majority party.

In light of such motivations, we consider two partisan hypotheses: (5) the distance between the median majority party member on the committee of referral and the median member of the majority party caucus should be positively related to the degree of amendment incursions; and (6) when the policy position of the majority party is more extreme than that of the referral committee and both are on the same side of the floor median (an indication of advantageous amendment opportunities for members of the minority party and/or the floor median), the committee's bill should be associated with a lower extent of outsider amendment incursions.

In addition, King (1997) argues in his work on committee jurisdictions that the underlying politics of bill referral fits most closely with an informational perspective and to a lesser extent with a distributive view. He contends that the partisan and distributive theories are less effective in explaining and understanding the dynamics of decisions governing committee jurisdiction at the referral stage. Informational gains from specialization may also be obtained in the context of multiple referral in that under issue fragmentation among more than one committee "the final vehicle is likely to have been shaped by a collection of panels that, as a whole, is more heterogeneous and less biased than any single committee" (144). Thus, one implication of King's work that we test is the multiple referral hypothesis: (7) bills referred to multiple committees should have more protection from amendment challenges on the floor than bills considered by a single committee.

Finally, we control for two other factors that are likely to influence committee power as measured by the degree of outsider amendment incursions: waivers in special rules and the degree of urgency associated with the bill. From time to time, the Rules Committee allows authorizing language in an appropriations bill and appropriations language in an authorization bill. These, by their very nature, represent potential incursions of one committee into the turf of another that should be controlled for. So, we offer the following waiver hypotheses: (8) bills considered under rules that waive restrictions on appropriations (or authorization) language in authorization (or appropriations) bills are less protected from floor amendment challenges on the part of jurisdictional competitors. Second, measures considered "mustpass" are more likely to receive floor protection than more "traditional" legislation because of the desire to expedite their consideration. Thus, the urgency hypothesis holds that: (9) urgent measures (e.g., supplemental and 
emergency appropriations, debt limit extensions, etc.) are more likely to be protected from amendment challenge on the floor.

\section{Data and Measures}

The data in this analysis are drawn from all bill-rule pairings and their corresponding floor amendments for the 97th, 98th, 104th, and 105th Congresses. A bill-rule pairing represents the bill and the particular special rule used to bring it to the House floor for debate. This provides a total of 367 bill-rule pairings and 1363 amendments. ${ }^{10}$ Our analysis aggregates the amendments to correspond with each individual bill because the special rules governing consideration of amendments are handed down at the bill level. This allows us to assess the extent to which particular bills faced amendments from non-committee members (e.g. outsider incursions) and allows for comparisons based on the characteristics of the individual bills.

The dependent variable employed in the analysis relates to committee power in that it measures the extent that a committee maintains control over a given bill (as determined by the rule) and is protected from amendment challenges on the floor. So, a greater proportion of outsider amendments relative to total amendments reflects comparatively low levels of committee power while lower values reflect relatively high degrees of committee power over the bill. The dependent variable is thus based on the characteristics of the individual members that sponsor amendment challenges on the particular bills. ${ }^{11}$ The extent that special rules expand or restrict opportunities for outsider incursions will be reflected in the patterns of amendment challenges offered on a particular bill. In particular, an amendment incursion occurs when a non-committee member offers an amendment to a bill that was referred to another committee (and thus falls within its jurisdiction). Consequently, the dependent variable measures the relative frequency of amendments offered by non-committee, rank and file members to all amendments offered on a particular bill. The higher this proportion of amendments to the total offered on the bill, the greater the degree of amendment incursion, and thus the lower the level of committee power on that given bill and vice versa.

The measurement of our independent variables generally follows standard indexes used in the literature, but we briefly describe them here. A summary is also presented in the Appendix. Following Krehbiel (1991), we capture the degree of legislative specialization in terms of the number of laws cited in the bill. We control for heterogeneity in two ways. We utilize Krehbiel's (1991) original construct that measures the signed difference between the standard deviation of committee members' NOMINATE scores and those of the floor. As noted above, King (1997) suggests that multiple 
referral increases the heterogeneity of committee signals, and Krehbiel (1991) includes this variable as a measure of committee heterogeneity. Because of this, we include a simple indicator variable tapping whether a bill was referred to more than one committee. We also utilize Krehbiel's (1991) outlier construct in the analysis as the median ideological distance between the committee of referral and the floor.

To assess the distributive hypothesis, we simply include a dichotomous variable capturing whether a bill was referred to a constituency committee. ${ }^{12}$ For the partisan hypotheses, we measure the degree of partisan interest in protecting the referral committee's turf from amendment challenges in two ways. First, we compute the distance between the NOMINATE scores of the median majority party committee member and the median member of the majority party caucus. The second measure is a dichotomous variable taking the value one when the majority party median is more extreme than the referral committee median and both are on the same side of the chamber median, and zero otherwise.

Finally, the control variables capturing rule waivers and bill urgency are also simple indicator measures. Bills are coded as urgent measures if they are continuing, supplemental, or emergency appropriations or if they extend the debt limit ceiling. Similarly, bills considered under a rule waiving points of order against including appropriations language in an authorization bill, and those waiving points of order against authorization language in an appropriations bill, are coded accordingly.

\section{Empirical Results and Discussion}

We begin by looking at the mean distribution of our dependent variable across the four Congresses. Much has been written recently of the changing nature of committee power, and the ways in which committees have come to be dominated by the majority party in particular (Cohen 1999). Most noticeably in the 104th and succeeding Congresses, though beginning earlier, the majority party leadership often found it beneficial to draft legislation outside the bounds of the formal committee structure, frequently sending the finished product through the committee for a rubber stamp before bringing it to the floor. Furthermore, the leadership used rules to structure the debate and amending processes so as to stave off potentially hostile policy challenges that would change the committee product. Thus, one gauge of our dependent variable might be the extent to which it picks up this aspect of variation in committee power.

Table 2 provides an aggregate summary of our dependent variable, amendment incursions, across the Congresses covered in our analysis. The pattern suggests that, in line with recent findings, bills faced lower propor- 
tions of amendment challenges on the floor as the congressional parties became more homogenous and the leadership took fuller advantage of its procedural prerogatives. While this might be a function of the jurisdictional realignment that occurred at the start of the 104th Congress, Baumgartner, Jones, \& MacLeod (2000) have suggested that such reforms do not have a significant impact on jurisdictional clarity. Of course, Table 2 presents only a limited picture of the factors that we expect to be important in influencing a committee's ability to protect bills within its jurisdictional boundaries. We turn next to a multivariate model based on the measures described in the preceding section to explain variation in amendment incursions bill by bill.

Our dependent variable is a proportion measured as the number of amendments offered to a bill by non-committee members divided by the total number of amendments offered on that bill. As such, it ranges from zero (no amendment incursion) to one (full amendment incursion) or from high committee power to low committee power, and given its bounded nature lends itself to tobit regression analysis. ${ }^{13}$ All the bills in the analysis were brought to the floor by a special rule, so the amendment activity on a bill is constrained by the extent to which the rule protects or opens it to challenges on the floor. The estimates of the model are presented in Table 3.

We begin with the results relating to informational theory. Interestingly, when a committee is considered an outlier, there is no evidence that it is more likely to be challenged on the floor. Similarly, the coefficient for committee heterogeneity, which the theory suggests should be negative, also appears not to exert a distinguishable effect on the degree of amendment incursion a committee faces on the floor. The variable for the number of laws cited, while significant, is in the opposite direction suggested by informational theory and its substantive effect is quite small. Finally, the multiple referral variable, while negative (as predicted), is not significant at conventional levels $(p=.096) .{ }^{14}$ As a whole, the variables drawn from informational theory, which holds that higher degrees of efficiency in informational transmission should be rewarded with greater levels of protection on the floor, offer little in the way of explaining the actual amendment patterns we observe under special rules in the House.

The variables capturing the degree of urgency of the bill and whether or not it was referred to a constituency committee also fail to reach significance at conventional levels, though each is in the predicted direction. Recall that as predicted by distributive theory, a measure will be more likely to receive protection on the floor so as to prevent an underlying logroll from unraveling. Similarly, the literature generally controls for the expectation that must pass legislation will be protected in order to stave off challenges that could hinder speedy enactment. 
278 | Charles J. Finocchiaro and Bryan W. Marshall

Table 2. Average Proportion of Amendment Incursion on Bills with Special Rules

\begin{tabular}{lcc}
\hline Congress & Turf Incursion & Number of Bills \\
\hline 97 th & 0.35 & 71 \\
98 th & 0.36 & 93 \\
104 th & 0.30 & 117 \\
105 th & 0.24 & 87 \\
\hline
\end{tabular}

Table 3. Tobit Regression of Amendment Incursion via Floor Amendments

\begin{tabular}{lcc}
\hline Variable & Coefficient & Standard Error \\
\hline Committee Outlier & -.398 & .808 \\
Heterogeneity & -1.238 & 1.566 \\
Laws Cited & $.006^{*}$ & .003 \\
Multiple Referral & -.217 & .130 \\
Urgency & -.264 & .171 \\
Constituency Committee & -.108 & .147 \\
Waiver of Authorization Rule & $.957^{* *}$ & .164 \\
Waiver of Appropriation Rule & $.432^{*}$ & .146 \\
Majority Party Distance & $2.540^{* *}$ & .975 \\
Party Median & $-.312^{*}$ & .122 \\
Constant & -.107 & .148 \\
$\mathrm{~N}$ & \multicolumn{2}{c}{367} \\
LL & \multicolumn{2}{c}{815.308} \\
$\chi^{2}$ & \multicolumn{2}{c}{}
\end{tabular}

Note: Dependent variable is the proportion of amendments to the bill offered by rank and file members who did not hold a seat on the committee(s) of referral.

* Significant at $\mathrm{p}<0.05, * * \mathrm{p}<0.01$. 
The waiver variables, on the other hand, do detect the predicted relationship between the choices of the Rules Committee regarding amendment access and the amendment patterns we observe on the floor. As predicted, when the Rules Committee waives the rule barring authorization language in an appropriations bill, we observe a marked increase in amendment incursion. The coefficient for this variable, which is significant, suggests that such waivers lead to a dramatic increase in non-committee members attempting to change the referral committee's product. Similarly, when the rule prohibiting appropriations language in authorization bills is waived, there is about a 43 percent increase in non-committee member challenges via floor amendments.

The final two variables included in our model tap the potential impact of partisan factors in explaining amending behavior. We hypothesized committees more closely representing the majority party's interests on policy grounds are more likely to be protected from amendment challenges on the floor. We find support for this claim in the coefficient estimates of both partisan variables. As the ideological distance between the median of the committee of referral and the median of the majority party grows, indicating less party representativeness, bills face significantly more amendment incursion on the floor. For instance, a bill considered by the most outlying committee in terms of the majority party's median member encounters about 73 percent more amendment challenges than a measure referred to a committee whose median and that of the party do not diverge. Additionally, when the majority party median is more extreme than the referral committee median and both are on the same side of the floor median, indicating an increased incentive for the majority party controlled Rules Committee to protect the committee's product, we see about a 31 percent decline in the proportion of amendments offered by non-committee members challenging the committee's proposal.

While many studies have documented the significant role of parties in areas such as the rules process, in handing out committee assignments, and in pressuring members' floor voting, we find them to play a significant role in brokering committee power, or more specifically access to committee bills, at the floor stage. King (1997) has insightfully argued that the processes governing jurisdictional arrangements are much more permeable than the previous literature had discovered. Our findings add to this by suggesting that one element of the permeability of committee turf can result from special rule decisions subsequent to the initial referral stage. Moreover, our results reflect that much of this important process seems to be dominated by partisan, rather than informational or distributive considerations. 


\section{Conclusions}

Our analysis highlights the importance of post-referral procedural decisions in shaping committee power bill by bill. We have emphasized a different process that governs the relevance of jurisdictional concerns, one that suggests turf wars do not end at the exit to the House Parliamentarian's office. Rather, subsequent battles are sometimes waged during various stages of the post-referral legislative process. We have argued that a committee's jurisdictional control over bills are not necessarily fixed at the referral stage, but can be infringed upon at least temporarily due to decisions made by the Rules Committee via special rules. More importantly though, the results reflect that special rule decisions do indeed have committee power at stake. As evidenced in the tobit analysis, a committee's control over particular bills at the floor stage can be affected by the extent to which amendment rights are granted to outsiders.

Certainly, King's (1997) analysis provides insight into informational considerations governing jurisdictional politics and the importance of those factors on bill referral decisions. We do not dispute King's claim that informational mechanisms underlie the referral decision, nor do we assert that procedural choices relating to amendment rights somehow permanently alter the boundaries of committee jurisdictions. However, we do find that the referral decision is not the only, or even the most important, decision determining how Congress sorts out the politics of committee turf and committee power more generally.

The results from Tables 2 and 3 challenge the idea that a committee's legislative prerogatives set at the referral stage are fixed. Procedural powers granted via special rules are neither constant nor trivial, as evidenced by the case study illustrating the Rules Committee's handling of the transportation bill and from the empirical results across four congresses examined here. That is, whether we look at turf in the context of the right of a committee to be the first mover (through referral and reporting - the essential issue in the case of the transportation appropriations bill) or a committee's interest in protecting its proposals once they reach the floor, the Rules Committee can and does play an influential role in determining not only jurisdictional integrity, but also committee power. The tobit analysis was constructed so as to test expectations drawn from the theories of legislative organization. While we found that amendment incursion declines on multiply referred bills, which supports some of King's assertions and parallels informational theory, this is the only informational factor that appears to play a role consistent with the theory. Our findings also suggest an important effect via waivers, which to date have not been recognized in the literature on committee jurisdictions nor for their relevance to committee power. 
In addition, the partisan variables were not only significant statistically and substantively, but they support partisan expectations regarding the conditions under which the majority party might be expected to protect the jurisdictional boundaries established at referral or to open them to challenge on the floor. This suggests further that the majority party plays an important role in shaping the negative power of committees (Smith 1989). That is, the granting of amendment rights directly influences the committee's capacity to restrict the policy alternatives available to the rest of the House. The results show that patterns in amendment rights are largely a function of partisan interests. More importantly then, this suggests that committee power and the incentives for committee specialization respond to and are governed by the majority party.

We set out to consider a relatively unstudied issue - that of committee power in the House of Representatives, and the use of special rules in framing amendments in particular. We sought to establish whether or not postreferral decisions (like special rules) have a substantial impact on committee power over particular bills within committee jurisdictions, and if so, what factors explain them. The case study of the 1994 Transportation appropriations bill as well as the systematic analysis explaining variation in amendment incursions during four post-reform congresses shows that special rule decisions do have a non-trivial impact on committee turf and, thus, committee power. More importantly, the brokering of committee power through special rules has implications for theories of legislative organization. While special rule decisions and other comparatively late stages of the legislative process rarely serve to alter the foundational jurisdictional framework of bill referral, they do possess potentially important implications for committee power and for understanding the increasingly important role of the majority party in House decision making. To the extent that post-referral decisions like these can shape the ability of outside members to challenge committee products on the floor, the importance of establishing committee jurisdictional boundaries at the referral stage is necessarily diminished. Although these results do not supplant the importance of the initial bill referral stage, to the extent that jurisdictional boundaries are endogenous with respect to special rules, the focus on these later stages tells us more about a previously unstudied aspect of legislative politics that helps in explaining the degree to which a committee's success in winning turf wars at the referral stage is likely to carry with it future successes in protecting committee products once they leave the committee room. 


\section{APPENDIX \\ Independent Variables Used in Tobit Model Explaining Turf Incursion on the Floor}

1. Heterogeneity-Computed as the signed difference between the standard deviation W-Nominate scores for the referral committee(s) and the entire chamber.

2. Committee Outlier-Computed as the absolute difference between the median NOMINATE score of the referral committee(s) and the median of the chamber.

3. Laws Cited - Count of number of laws cited and/or repealed by the relevant bill.

4. Constituency Committee-Dummy variable indicating whether the bill was referred to a constituency committee (Deering and Smith 1997: 64). These include Agriculture, Armed Services, Interior, Merchant Marine, Public Works, Science, Small Business, and Veterans' Affairs.

5. Majority Party Distance - This variable is computed as the absolute difference between the median position of the referral committee and the median of the majority party as measured by NOMINATE.

6. Party Median-This variable is coded 1 when the majority party median is more extreme than the referral committee median and both are on the same side relative to the floor median; and coded 0 otherwise.

7. Multiple Referral-This variable is coded 1 indicating multiple referral and 0 for bills with single referral.

8. Authorization Waiver-This variable is coded 1 when the special rule contains a waiver against House prohibition for authorization language in appropriations legislation; and coded 0 otherwise.

9. Appropriations Waiver-This variable is coded 1 when the special rule contains a waiver against House prohibition of appropriations in authorization legislation; and coded 0 otherwise.

10. Urgency - This variable is coded 1 for bills that extend the debt limit ceiling, continuing resolutions, supplemental, and emergency appropriations.

\section{NOTES}

${ }^{1}$ Shepsle and Weingast suggest further that if closed rules governed all bills, then even the ex post veto power of committees in conference would be far less vital (1987).

${ }^{2} \mathrm{HR} 1757$ was later vetoed by President Clinton.

${ }^{3}$ The House passed the Tauzin-Dingell bill intact by a $273-157$ margin $(C Q W$ $3 / 2 / 02,581$ ).

${ }^{4} \mathrm{~A}$ waiver can set aside any standing rule(s) of the House for considering legislation on the floor.

${ }^{5}$ Aldrich and Rohde (2000) suggest that one key change since the 100th Congress in the appropriations process has been the majority party leadership's use of waivers to embed policy riders in must pass appropriations legislation.

${ }^{6}$ The accounts of the turf war over the Transportation appropriations bill are from Congressional Quarterly Weekly (7/24/93, 1946-1947; 9/25/93, 2535-2538).

${ }^{7}$ House Rule 21 allows members to bring a point of order to strike any part of an appropriations bill that provides money for unauthorized projects unless they have already received funding and are in progress. 
${ }^{8}$ The new rule also contained a self-executing provision which upon adoption would provide for two special projects near Mineta's district that had been dropped from the revised bill (CQW 9/25/93, 2535).

${ }^{9}$ This is particularly important in the context of multiple referrals given the additional veto points added by this procedure and its potential for stymieing congressional action on an issue (Davidson and Oleszek 1992).

${ }^{10} \mathrm{We}$ originally began with 534 bill-rule pairings, but the data for our analysis include only those bills with amendments on which a recorded vote was taken. We do not include bill-rule pairings that had only amendments considered by voice vote because they lack the type of overt conflict we are interested in explaining. Additionally, because no amendments are observed for bills with closed rules, these pairings were coded the value zero for our dependent variable.

${ }^{11}$ This is, admittedly, only one conceptualization of committee power. An alternative might be to examine the total number of non-committee sponsored amendments rather than the proportion, or even the number of successful non-committee sponsored amendments. While we believe the proportion is more tractable theoretically and empirically, it is worthwhile to note that the empirical results are substantively the same when employing alternative measures. Furthermore, amendments of both committee and noncommittee origin succeed at a rate of about one in three, while the overall mix between the groups is nearly identical.

${ }^{12}$ We follow Deering and Smith (1997) for the typology of constituency committees. The coding of this variable for our analysis is described in the Appendix.

${ }^{13}$ In the context of right and/or left censoring of the dependent variables, traditional OLS estimates are biased and inconsistent. Thus we estimate the tobit model using maximum likelihood. Interestingly, the results are identical in terms of sign and significance for all parameters but one-multiple referral, which is not significant using tobit.

${ }^{14}$ While not as closely linked to informational theory, both King (1997) and Krehbiel (1991) suggest that bills referred to more than one committee are generally more informative due to the broader perspectives incorporated across the panels' members.

\section{REFERENCES}

Aldrich, John H., and David W. Rohde. 2000. The Republican Revolution and the House Appropriations Committee. Journal of Politics 62:1-33.

Bach, Stanley, and Steven S. Smith. 1988. Managing Uncertainty in the House of Representatives: Adaptation and Innovation in Special Rules. Washington, DC: Brookings Institution.

Baron, David P., and John A. Ferejohn. 1989. Bargaining in Legislatures. American Political Science Review 89:1181-1206.

Baumgartner, Frank R., Bryan D. Jones, and Michael C. MacLeod. 2000. The Evolution of Legislative Jurisdictions. Journal of Politics 62:321-349.

Cohen, Richard E. 1999. Crackup of the Committees. National Journal, July 31, p. 2210.

Congressional Quarterly Weekly $(C Q W)$, various issues.

Congressional Record (CR), various issues.

Cooper, Joseph, and David W. Brady. 1981. Institutional Context and Leadership Style: The House from Cannon to Rayburn. American Political Science Review 75:411425. 
Cox, Gary W., and Mathew D. McCubbins. 1993. Legislative Leviathan: Party Government in the House. Berkeley: University of California Press.

Davidson, Roger H., and Walter J. Oleszek. 1992. From Monopoly to Management: Changing Patterns of Committee Deliberation. In The Postreform Congress, ed. Roger H. Davidson. New York: St. Martin's Press.

Davidson, Roger H., Walter J. Oleszek, and Thomas Kephart. 1988. One Bill, Many Committees: Multiple Referrals in the U.S. House of Representatives. Legislative Studies Quarterly 13:3-28.

Deering, Christopher J., and Steven S. Smith. 1997. Committees in Congress, 3d ed. Washington, DC: CQ Press.

Dion, Douglas, and John Huber. 1996. Procedural Choice and the House Committee on Rules. Journal of Politics 58:25-53.

Ferejohn, John. 1974. Pork Barrel Politics: Rivers and Harbors Legislation, 1947-1968. Stanford, CA: Stanford University Press.

Jones, Bryan D., Frank R. Baumgartner, and Jeffery C. Talbert. 1993. The Destruction of Issue Monopolies in Congress. American Political Science Review 87:657-671.

King, David C. 1997. Turf Wars: How Congressional Committees Claim Jurisdiction. Chicago: University of Chicago Press.

Krehbiel, Keith. 1991. Information and Legislative Organization. Ann Arbor: University of Michigan Press.

Krehbiel, Keith. 1997. Restrictive Rules Reconsidered. American Journal of Political Science 41:919-944.

Marshall, Bryan W. 2002. Explaining the Role of Restrictive Rules in the Postreform House. Legislative Studies Quarterly 27:61-85.

Mayhew, David R. 1974. Congress: The Electoral Connection. New Haven, CT: Yale University Press.

Oleszek, Walter J. 2001. Congressional Procedures and the Policy Process, 5th ed. Washington, DC: CQ Press.

Oppenheimer, Bruce I. 1977. "The Rules Committee: New Arm of Leadership in a Decentralized House." In Congress Reconsidered, eds. Lawrence C. Dodd and Bruce I. Oppenheimer. New York: Praeger.

Polsby, Nelson W. 1968. The Institutionalization of the U.S. House of Representatives. American Political Science Review 62:148-168.

Rohde, David W. 1991. Parties and Leaders in the Postreform House. Chicago: University of Chicago Press.

Shepsle, Kenneth A., and Barry R. Weingast. 1987. The Institutional Foundations of Committee Power. American Political Science Review 81:85-105.

Shipan, Charles R. 1992. Individual Incentives and Institutional Imperatives: Committee Jurisdiction and Long-Term Health Care. American Journal of Political Science 36:877-895.

Sinclair, Barbara. 1992. The Emergence of Strong Leadership in the 1980s House of Representatives. Journal of Politics 54:657-684.

Sinclair, Barbara. 2002. Do Parties Matter? In Party, Process, and Political Change in Congress: New Perspectives on the History of Congress, eds. David W. Brady and Mathew D. McCubbins. Stanford: Stanford University Press.

Smith, Steven S. 1989. Call to Order: Floor Politics in the House and Senate. Washington, DC: The Brookings Institution.

Weingast, Barry R., and William J. Marshall. 1988. The Industrial Organization of Congress; or, Why Legislatures, Like Firms, Are Not Organized As Markets. Journal of Political Economy 96:132-163. 